\title{
Simultaneous nitrification and denitrification in step feeding biological nitrogen removal process
}

\author{
ZHU Gui-bing ${ }^{1,2}$, PENG Yong-zhen ${ }^{1,3, *}$, WU Shu-yun ${ }^{1}$, WANG Shu-ying ${ }^{3}$, XU Shi-wei $^{4}$ \\ 1. School of Municipal and Environmental Engineering, Harbin Institute of Technology, Harbin 150090, China \\ 2. Research Center for Eco-Environmental Sciences, Chinese Academy of Sciences, Beijing 100085, China. E-mail: gbzhu@rcees.ac.cn \\ 3. Key Laboratory of Beijing Water Quality Science and Water Environment Recovery Engineering, \\ Beijing University of Technology, Beijing 100022, China \\ 4. Beijing Drainage Group Co. Ltd., Beijing 100038, China
}

Received 9 October 2006; revised 6 December 2006; accepted 4 April 2007

\begin{abstract}
The simultaneous nitrification and denitrification in step-feeding biological nitrogen removal process were investigated under different influent substrate concentrations and aeration flow rates. Biological occurrence of simultaneous nitrification and denitrification was verified in the aspect of nitrogen mass balance and alkalinity. The experimental results also showed that there was a distinct linear relationship between simultaneous nitrification and denitrification and DO concentration under the conditions of low and high aeration flow rate. In each experimental run the floc sizes of activated sludge were also measured and the results showed that simultaneous nitrification and denitrification could occur with very small size of floc.
\end{abstract}

Key words: biological nitrogen removal; dissolved oxygen; floc size; simultaneous nitrification and denitrification; step feeding process

\section{Introduction}

Because of the stringent nutrient levels being required in the effluents to protect lakes and other natural water from eutrophication, removal of nitrogen from discharged wastewater has been required in many wastewater treatment plants. The step-feeding anoxic/aerobic biological nitrogen removal process is characterized by high total nitrogen removal efficiency and unnecessary internal recycle. During the last decade, many researchers have put much attention to this process and drawn many valuable conclusions (Larrea et al., 2001; Zhu et al., 2005). Moreover, nitrogen loss and simultaneous nitrification and denitrification in step feeding process were also reported by researchers (Gorgun et al., 1996; Zhu et al., 2007a).

Simultaneous nitrification and denitrification (SND) implies that nitrification and denitrification occur concurrently in the same reaction vessel under identical overall operating conditions. SND is of particular interest in saving anoxic volume and in treatment wastewaters with low C:N ratio (Zhu et al., 2007b). The mechanism and explanation for SND can be divided into two broad categories. The physical and conventional explanation is that SND occurs as a consequence of DO concentration gradients within

Project supported by the Key International Cooperative Program of NSFC (No. 50521140075), the Hi-Tech Research and Development Program (863) of China (No. 2004AA601020) and the Attached Projects of "863" Project of Beijing Municipal Science and Technology (No. 20005186040421).*Corresponding author. E-mail: pyz@bjut.edu.cn. microbial flocs or biofilms due to diffusional limitations. The biological explanations for SND are in contrast to the traditional "engineering" conception of nitrification and denitrification. Microbiologists have reported the existence of aerobic denitrifiers as well as heterotrophic nitrifiers (Kim et al., 2005; Zhu et al., 2007b).

Previous researches showed that three principle factors, carbon supply, oxygen concentration and floc size, predominantly influenced SND (Zhu et al., 2007b). But there were still some unresolved problems. The large floc parameter was likely to promote the SND due to diffusional limitation of oxygen in the floc, whether small size parameter is adverse to SND was still not reported. In addition, it has not been reported in literature that denitrification reaction could be accomplished under high DO concentration condition and the relationship of DO concentration and SND. In the article, the SND in step feeding process was investigated. The main objective was to explain the relationship of DO concentration and SND.

\section{Material and methods}

\subsection{Reactor system}

A four stages step feeding biological nitrogen removal process made of plexiglass with a working volume of $80 \mathrm{~L}(800 \mathrm{~mm} \times 220 \mathrm{~mm} \times 500 \mathrm{~mm})$ was used in this study (Fig.1). The volume of four stages was the same and the volume ratio of anoxic to oxic in each stage 


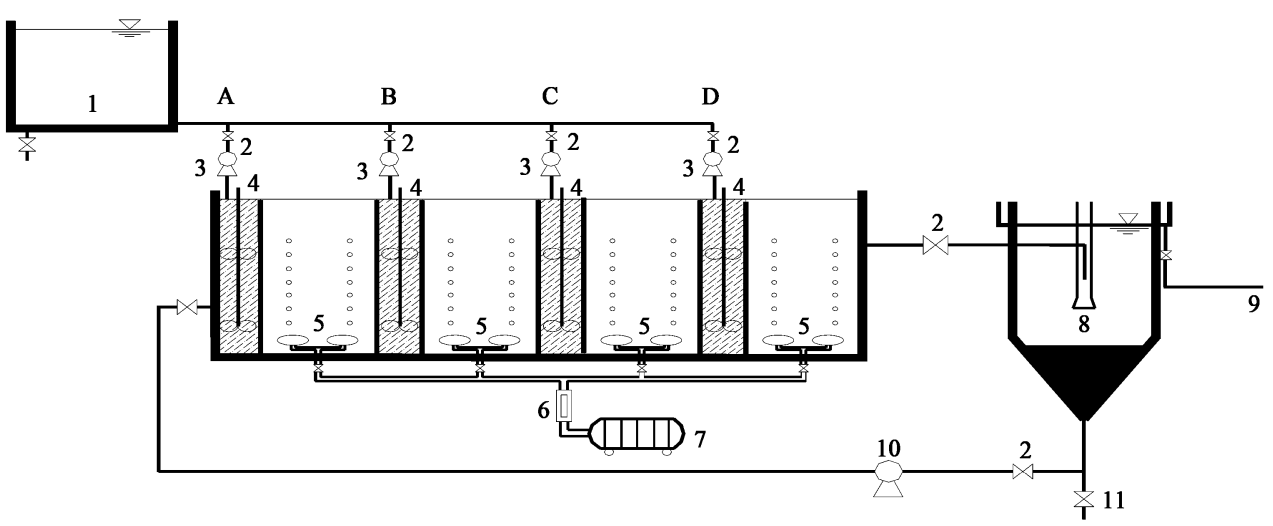

Fig. 1 Schematic diagram of step feeding biological nitrogen removal process. (1) influent tank; (2) check value; (3) feeding pump; (4) mechanical mixer; (5) diffuser; (6) air flow meter; (7) air compressor; (8) secondary clarifier; (9) effluent; (10) return sludge pump; (11) waste sludge.

was maintained at 1:3.5. A mechanical mixer was used in anoxic zone to provide liquid mixed well. A number of outlets for sample analysis were emplaced with the distance of $20 \mathrm{~cm}$ from reactor bottom in each anoxic and aerobic zone. An air compressor with micropore diffuser was used for aeration. An air flow meter was used for controlling the airflow rate. The type of final clarifier was upright clarifier with a working volume of $30 \mathrm{~L}$.

\subsection{Experimental operating procedure}

The reactor feeding consisted of synthetic wastewater with characteristics similar to those of domestic wastewater (Watnabe et al., 1995). It was prepared by using tap water, dechlorinated by the use of sodium thiosulfate, and the addition of dosages of chemicals, as indicated in Table 1. During the experimental period, the solid retention time (SRT) was controlled at $18 \mathrm{~d}$ using hydraulic controlling approach (Zhu et al., 2007c).

The total influent flow rate was $240 \mathrm{~L} / \mathrm{d}$ and each stage was set at $60 \mathrm{~L} / \mathrm{d}$, respectively, which was controlled by four same peristaltic pumps (Model ESBN4, Iwaki Cop. Japan). The sludge return ratio was set at $50 \%$ of influent flow rate by a peristaltic pump. The experimental operating procedure is shown in Table 2. During each experiment the step feeding process was operated for more than two sludge ages ( $36 \mathrm{~d})$.

\subsection{Samples and analytical procedures}

The parameters measured included floc size, temperature, DO, COD, $\mathrm{NH}_{4}^{+}-\mathrm{N}, \mathrm{NO}_{2}^{-}-\mathrm{N}, \mathrm{NO}_{3}{ }^{-}-\mathrm{N}, \mathrm{TN}$ and alkalinity. Samples were prepared by filtering with 0.45 $\mu \mathrm{m}$ Whatman filter papers. The DO measurements were conducted using YSI Model 58 DO meter. The floc size

Table 1 Composition of synthetic wastewater

\begin{tabular}{ll}
\hline Compound & Concentration $(\mathrm{mg} / \mathrm{L})$ \\
\hline Brewery wastewater & 1080 \\
$\mathrm{NH}_{4} \mathrm{Cl}$ & 114.6 \\
$\mathrm{NaHCO}_{3}$ & 900.0 \\
$\mathrm{KH}_{2} \mathrm{PO}_{4}$ & 105.0 \\
$\mathrm{MgSO}_{4} \cdot 7 \mathrm{H}_{2} \mathrm{O}$ & 150.0 \\
$\mathrm{NaCl}$ & 110.0 \\
$\mathrm{CaCl}$ & 85.5 \\
$\mathrm{ZnSO}_{4}$ & 90.0 \\
\hline
\end{tabular}

Table 2 Experimental operating procedure

\begin{tabular}{llll}
\hline Lab & $\begin{array}{l}\text { Influent } \\
\text { TKN }(\mathrm{mg} / \mathrm{L})\end{array}$ & $\begin{array}{l}\text { Influent } \\
\text { COD }(\mathrm{mg} / \mathrm{L})\end{array}$ & $\begin{array}{l}\text { Aeration } \\
\text { flowrate }\left(\mathrm{m}^{3} / \mathrm{h}\right)\end{array}$ \\
\hline E1 & 40 & 268 & 0.6 \\
E2 & 40 & 345 & 0.6 \\
E3 & 55 & 272 & 0.6 \\
E4 & 55 & 348 & 0.6 \\
E5 & 46 & 278 & 1.2 \\
E6 & 46 & 340 & 1.2 \\
E7 & 46 & 450 & 1.2 \\
\hline
\end{tabular}

was measured using Liquid Particle Counting System Model 9703 (HIAC Royco) with the sensor HRLD-400. All analyses were performed according to the Standard Methods (APHA, 1995).

\section{Results and discussion}

\subsection{Simultaneous nitrification and denitrification}

The original experimental observed mass of ammonia loss and $\mathrm{NO}_{x}-\mathrm{N}$ formation in seven experiments are shown in Table 3. It shows that the mass of $\mathrm{NH}_{3}-\mathrm{N}$ decay was obviously larger than the mass of $\mathrm{NO}_{x}-\mathrm{N}$ formation, especially in the former stage of the step feeding process. But this phenomenon of nitrogen loss could not definitely be attributed to the simultaneous nitrification and denitrification. In step feeding process suspended solids gradient along the reactors was formed because of influent step feeding. The large amounts of biomass in the former stage grew and reproduced rapidly with abundant organic substrate. It is well known that nitrogen is also needed in the process of metabolisms of activated sludge microorganisms. So it is necessary to make certain that the nitrogen loss should be attributed to the assimilation of activated sludge microorganisms or simultaneous nitrification and denitrification.

In steady state of activated sludge process the mass of sludge discharged is equal to the mass of microorganism growth and formation. The nitrogen consumption because of cell assimilation would be calculated with the cell formula $\left(\mathrm{C}_{5} \mathrm{H}_{7} \mathrm{NO}_{2}\right)$ (Bruce and Perry, 2001), in which $\mathrm{N}$ is accounted for about $12 \%$. The calculated results of nitrogen loss for assimilation during different experimental 
Table 3 Observed mass of ammonia loss and $\mathrm{NO}_{x}$-N formation during different experimental operating conditions

\begin{tabular}{|c|c|c|c|c|c|c|c|}
\hline \multirow[t]{2}{*}{ Lab } & \multirow[t]{2}{*}{ Stage } & \multicolumn{2}{|c|}{$\mathrm{NH}_{3}-\mathrm{N}(\mathrm{mg} / \mathrm{L})$} & \multirow{2}{*}{$\begin{array}{l}\text { Mass of } \mathrm{NH}_{3}-\mathrm{N} \\
\text { decay }(\mathrm{g} / \mathrm{d})(1)\end{array}$} & \multicolumn{2}{|c|}{$\mathrm{NO}_{x}-\mathrm{N}(\mathrm{mg} / \mathrm{L})$} & \multirow{2}{*}{$\begin{array}{l}\text { Mass of } \mathrm{NO}_{x}-\mathrm{N} \\
\text { formation }(\mathrm{g} / \mathrm{d})(2)\end{array}$} \\
\hline & & $\begin{array}{l}\text { Start of } \\
\text { aerobic zone }\end{array}$ & $\begin{array}{l}\text { End of } \\
\text { aerobic zone }\end{array}$ & & $\begin{array}{l}\text { Start of } \\
\text { aerobic zone }\end{array}$ & $\begin{array}{l}\text { End of } \\
\text { aerobic zone }\end{array}$ & \\
\hline \multirow[t]{4}{*}{ E1 } & A & 14.2480 & 0.8220 & 2.4168 & 0.0000 & 7.8330 & 1.4100 \\
\hline & $\mathrm{B}$ & 10.0830 & 0.0000 & 2.4199 & 0.0000 & 5.9300 & 1.4232 \\
\hline & $\mathrm{C}$ & 8.0010 & 0.0000 & 2.4002 & 0.0000 & 4.9950 & 1.4986 \\
\hline & $\mathrm{D}$ & 6.1650 & 0.0000 & 2.2195 & 0.0000 & 4.1150 & 1.4815 \\
\hline \multirow[t]{4}{*}{ E2 } & A & 12.9000 & 2.6500 & 1.8451 & 0.0000 & 5.5420 & 0.9977 \\
\hline & $\mathrm{B}$ & 9.8900 & 1.8550 & 1.9284 & 0.0000 & 4.2190 & 1.0126 \\
\hline & $\mathrm{C}$ & 8.7200 & 1.3000 & 2.2260 & 0.0000 & 4.3500 & 1.3051 \\
\hline & $\mathrm{D}$ & 6.0950 & 0.2650 & 2.0988 & 0.0000 & 3.5310 & 1.2713 \\
\hline \multirow[t]{4}{*}{ E3 } & A & 18.0200 & 6.3600 & 2.0988 & 0.0000 & 6.5420 & 1.1777 \\
\hline & B & 14.5750 & 3.1800 & 2.7348 & 0.0000 & 6.8440 & 1.6426 \\
\hline & $\mathrm{C}$ & 13.2500 & 4.2400 & 2.7031 & 0.0000 & 5.5950 & 1.6786 \\
\hline & D & 11.3950 & 4.7700 & 2.3851 & 0.0000 & 4.3750 & 1.5751 \\
\hline \multirow[t]{4}{*}{$\mathrm{E} 4$} & A & 14.1750 & 6.0000 & 1.6214 & 0.0000 & 3.3750 & 0.6074 \\
\hline & B & 12.0000 & 5.5000 & 1.5300 & 0.0000 & 2.6020 & 0.6245 \\
\hline & $\mathrm{C}$ & 9.2000 & 5.2000 & 1.3200 & 0.0000 & 2.2800 & 0.6840 \\
\hline & $\mathrm{D}$ & 8.5000 & 3.0000 & 1.9800 & 0.0000 & 3.0730 & 1.1064 \\
\hline \multirow[t]{4}{*}{ E5 } & A & 11.4800 & 0.0000 & 2.2664 & 0.0000 & 8.7920 & 1.4826 \\
\hline & B & 10.7700 & 0.0000 & 2.5848 & 0.0000 & 9.0470 & 2.1713 \\
\hline & $\mathrm{C}$ & 8.7700 & 0.0000 & 2.7311 & 0.0000 & 7.4100 & 2.2231 \\
\hline & $\mathrm{D}$ & 7.2400 & 0.0000 & 2.6964 & 0.0000 & 6.3850 & 2.1987 \\
\hline \multirow[t]{4}{*}{ E6 } & A & 9.0200 & 0.0000 & 1.8236 & 0.0000 & 6.5830 & 1.0849 \\
\hline & B & 6.8900 & 0.0000 & 1.6536 & 0.0000 & 6.3750 & 1.253 \\
\hline & $\mathrm{C}$ & 6.0950 & 0.0000 & 1.7686 & 0.0000 & 5.4000 & 1.262 \\
\hline & $\mathrm{D}$ & 5.0350 & 0.0000 & 1.8127 & 0.0000 & 4.4060 & 1.2862 \\
\hline \multirow[t]{4}{*}{ E7 } & A & 11.3950 & 0.7950 & 1.9080 & 0.0000 & 6.7920 & 1.2226 \\
\hline & B & 7.9500 & 0.0000 & 1.9080 & 0.0000 & 6.4690 & 1.5526 \\
\hline & $\mathrm{C}$ & 8.2150 & 0.0000 & 2.4646 & 0.0000 & 6.3450 & 1.9034 \\
\hline & $\mathrm{D}$ & 6.6250 & 0.0000 & 2.3851 & 0.0000 & 5.1040 & 1.8374 \\
\hline Lab & Stage & $\begin{array}{l}\text { Mass of } N \text { loss } \\
(1)-(2)(g / d)\end{array}$ & $\begin{array}{l}\text { Total N loss } \\
\text { in system }(\mathrm{g} / \mathrm{d})\end{array}$ & $\begin{array}{l}\text { Discharge sludge } \\
\text { conc. }(\mathrm{mg} / \mathrm{L})\end{array}$ & $\begin{array}{l}\text { Discharge rate } \\
(\mathrm{mg} / \mathrm{d})\end{array}$ & $\begin{array}{l}\mathrm{N} \text { loss for } \\
\text { assimilation }(\mathrm{g} / \mathrm{d})\end{array}$ & $\begin{array}{l}\text { Average MLSS } \\
(\mathrm{mg} / \mathrm{L})\end{array}$ \\
\hline \multirow[t]{4}{*}{ E1 } & A & 1.0068 & 3.6432 & 7350 & 13.230 & 1.5876 & 4900 \\
\hline & B & 0.9967 & & & & & 3680 \\
\hline & $\mathrm{C}$ & 0.9017 & & & & & 2960 \\
\hline & $\mathrm{D}$ & 0.7380 & & & & & 2450 \\
\hline \multirow[t]{4}{*}{$\mathrm{E} 2$} & A & 0.8474 & 3.5116 & 7530 & 13.554 & 1.6265 & 4976 \\
\hline & B & 0.9158 & & & & & 3778 \\
\hline & $\mathrm{C}$ & 0.9209 & & & & & 2977 \\
\hline & $\mathrm{D}$ & 0.8275 & & & & & 2510 \\
\hline \multirow[t]{4}{*}{ E3 } & A & 0.9211 & 3.8479 & 7440 & 13.392 & 1.6070 & 4918 \\
\hline & B & 1.0922 & & & & & 3736 \\
\hline & $\mathrm{C}$ & 1.0246 & & & & & 2933 \\
\hline & $\mathrm{D}$ & 0.8100 & & & & & 2480 \\
\hline E4 & A & 1.014 & 3.4291 & 7680 & 13.824 & 1.6783 & 4995 \\
\hline & B & 0.9055 & & & & & 3790 \\
\hline & $\mathrm{C}$ & 0.636 & & & & & 3050 \\
\hline & $\mathrm{D}$ & 0.8736 & & & & & 2590 \\
\hline E5 & A & 0.7838 & 2.203 & 7518 & 13.532 & 1.6563 & 4947 \\
\hline & B & 0.4135 & & & & & 3772 \\
\hline & $\mathrm{C}$ & 0.508 & & & & & 2995 \\
\hline & $\mathrm{D}$ & 0.4977 & & & & & 2556 \\
\hline E6 & $\mathrm{A}$ & 0.7387 & 2.1724 & 7830 & 14.094 & 1.6731 & 4977 \\
\hline & B & 0.4006 & & & & & 3780 \\
\hline & $\mathrm{C}$ & 0.5066 & & & & & 3001 \\
\hline & $\mathrm{D}$ & 0.5265 & & & & & 2582 \\
\hline E7 & A & 0.6854 & 2.1496 & 7596 & 13.673 & 1.7107 & 5050 \\
\hline & B & 0.3554 & & & & & 3905 \\
\hline & $\mathrm{C}$ & 0.5611 & & & & & 3150 \\
\hline & D & 0.5477 & & & & & 2640 \\
\hline
\end{tabular}

operating conditions are shown in Table 3. From Table 3 it was obvious the mass of nitrogen loss in the system were larger than the mass of nitrogen loss for assimilation. So it could reasonably be speculated that there must be simultaneous nitrification and denitrification in the reactor.

The occurrence of SND was also verified with alkalinity variation in the reactor. The observed rates of alkalinity loss due to nitrification during different experimental operating conditions are shown in Table 4. From Table 4 the calculated results of alkalinity loss were all below the theoretical value of $7.14 \mathrm{mg} / \mathrm{L}$ (Bruce and Perry, 2001), average of $6.247 \mathrm{mg} / \mathrm{L}$, of alkalinity as $\mathrm{CaCO}_{3}$ per $\mathrm{mg}$ 
Table 4 Observed alkalinity consumption, rates of ammonia loss and $\mathrm{NO}_{x}$-N formation, DO concentration during different experimental operating conditions

\begin{tabular}{|c|c|c|c|c|c|c|c|c|c|}
\hline $\mathrm{Lab}$ & Stage & $\begin{array}{l}\text { Alkalinity } \\
\text { consumption } \\
(\mathrm{mg} / \mathrm{H})\end{array}$ & $\begin{array}{l}\frac{\Delta \text { Alkalinity }}{\Delta \mathrm{NH}_{3}-\mathrm{N}} \\
\text { (1) }\end{array}$ & $\begin{array}{l}\frac{\Delta \text { Alkalinity }}{\Delta \mathrm{NO}_{x}-\mathrm{N}} \\
\text { (2) }\end{array}$ & $\begin{array}{l}\text { Alkalinity } \\
\text { loss ratio } \\
(1):(2)\end{array}$ & $\begin{array}{l}\text { Rate of } \mathrm{NH}_{4} \\
\text { decay }\left(\mathrm{kgNH}_{4} /\right. \\
(\mathrm{kg} \mathrm{MLSS} \cdot \mathrm{d}))\end{array}$ & $\begin{array}{l}\text { Rate of } \mathrm{NO}_{3} \\
\text { formation }\left(\mathrm{kgNO}_{3} /\right. \\
(\mathrm{kg} \text { MLSS } \cdot \mathrm{d}))\end{array}$ & $\frac{\Delta \mathrm{NO}_{x}-\mathrm{N}}{\Delta \mathrm{NH}_{3}-\mathrm{N}}$ & $\begin{array}{l}\text { Average } \\
\text { DO }(\mathrm{mg} / \mathrm{L})\end{array}$ \\
\hline \multirow[t]{4}{*}{ E1 } & A & 675.00 & 6.7034 & 11.4898 & 0.5834 & 0.0322 & 0.0188 & 0.5839 & 0.3900 \\
\hline & B & 625.00 & 6.1986 & 10.5397 & 0.5881 & 0.0430 & 0.0253 & 0.5890 & 0.8500 \\
\hline & $\mathrm{C}$ & 562.50 & 5.6243 & 9.0090 & 0.6243 & 0.0533 & 0.0333 & 0.6250 & 0.9700 \\
\hline & $\mathrm{D}$ & 565.05 & 6.1103 & 9.1543 & 0.6675 & 0.0592 & 0.0395 & 0.6670 & 1.9700 \\
\hline \multirow[t]{4}{*}{ E2 } & A & 468.75 & 6.0976 & 11.2776 & 0.5407 & 0.0246 & 0.0133 & 0.5390 & 0.1670 \\
\hline & B & 560.00 & 6.9695 & 13.2733 & 0.5251 & 0.0343 & 0.0180 & 0.5262 & 0.2630 \\
\hline & $\mathrm{C}$ & 625.00 & 6.7385 & 11.4942 & 0.5863 & 0.0495 & 0.0290 & 0.5850 & 0.5460 \\
\hline & $\mathrm{D}$ & 525.00 & 6.0034 & 9.9122 & 0.6057 & 0.0560 & 0.0339 & 0.6050 & 0.8460 \\
\hline \multirow[t]{4}{*}{ E3 } & A & 581.25 & 6.6467 & 11.8466 & 0.5611 & 0.0280 & 0.0157 & 0.5600 & 0.3600 \\
\hline & B & 675.01 & 5.9237 & 9.8627 & 0.6006 & 0.0486 & 0.0292 & 0.6000 & 0.6000 \\
\hline & $\mathrm{C}$ & 656.25 & 5.8269 & 9.3834 & 0.6210 & 0.0601 & 0.0373 & 0.6200 & 0.9360 \\
\hline & D & 675.00 & 6.7925 & 10.2858 & 0.6604 & 0.0636 & 0.0420 & 0.6600 & 1.4800 \\
\hline \multirow[t]{4}{*}{$\mathrm{E} 4$} & A & 266.25 & 5.7490 & 10.5185 & 0.5466 & 0.0148 & 0.0081 & 0.5490 & 0.1670 \\
\hline & B & 290.00 & 6.4444 & 11.1452 & 0.5782 & 0.0192 & 0.0111 & 0.5780 & 0.2630 \\
\hline & $\mathrm{C}$ & 350.00 & 7.0000 & 12.2807 & 0.5700 & 0.0267 & 0.0152 & 0.5710 & 0.5460 \\
\hline & $\mathrm{D}$ & 525.00 & 6.3636 & 11.3895 & 0.5587 & 0.0528 & 0.0295 & 0.5580 & 0.7680 \\
\hline \multirow[t]{4}{*}{ E5 } & A & 431.25 & 5.0087 & 6.5400 & 0.7659 & 0.0276 & 0.0211 & 0.7660 & 2.1630 \\
\hline & B & 750.00 & 6.9638 & 8.2901 & 0.8400 & 0.0460 & 0.0386 & 0.8400 & 4.0900 \\
\hline & $\mathrm{C}$ & 625.01 & 5.7013 & 6.7477 & 0.8449 & 0.0585 & 0.0494 & 0.8440 & 3.9300 \\
\hline & $\mathrm{D}$ & 449.99 & 4.1436 & 4.6985 & 0.8819 & 0.0695 & 0.0613 & 0.8818 & 4.5630 \\
\hline \multirow[t]{4}{*}{ E6 } & A & 468.75 & 6.9290 & 9.4941 & 0.7298 & 0.0216 & 0.0158 & 0.7326 & 2.4630 \\
\hline & B & 475.00 & 6.8940 & 7.4509 & 0.9253 & 0.0294 & 0.0272 & 0.9266 & 4.3800 \\
\hline & $\mathrm{C}$ & 475.00 & 6.2346 & 7.0370 & 0.8860 & 0.0406 & 0.0360 & 0.8866 & 4.4700 \\
\hline & $\mathrm{D}$ & 337.50 & 4.4687 & 5.1067 & 0.8751 & 0.0483 & 0.0423 & 0.8750 & 4.1600 \\
\hline \multirow[t]{4}{*}{ E7 } & A & 562.50 & 7.0755 & 11.0424 & 0.6408 & 0.0254 & 0.0163 & 0.6430 & 1.7830 \\
\hline & B & 540.00 & 6.7925 & 8.3476 & 0.8137 & 0.0339 & 0.0276 & 0.8130 & 3.7400 \\
\hline & $\mathrm{C}$ & 660.00 & 6.4273 & 8.3216 & 0.7724 & 0.0548 & 0.0423 & 0.7720 & 3.6800 \\
\hline & $\mathrm{D}$ & 705.00 & 7.0943 & 9.2084 & 0.7704 & 0.0636 & 0.0490 & 0.7710 & 3.8260 \\
\hline
\end{tabular}

of ammonia oxidized. The low alkalinity consumption rates could be attributed to the occurrence of simultaneous nitrification and denitrification, because alkalinity would also be affected by two processes occurring at the same time.

The theoretical rate of alkalinity production during denitrification is $3.57 \mathrm{mg}$ of alkalinity per $\mathrm{mg}$ of $\mathrm{NO}_{x^{-}}$ $\mathrm{N}$ reduced. Theoretically, the ratio of observed alkalinity destruction rates with respect to ammonia loss and $\mathrm{NO}_{x}-\mathrm{N}$ formation is corresponded to the ratio of observed rates for $\mathrm{NO}_{x}-\mathrm{N}$ formation and ammonia loss. Fig. 2 presents

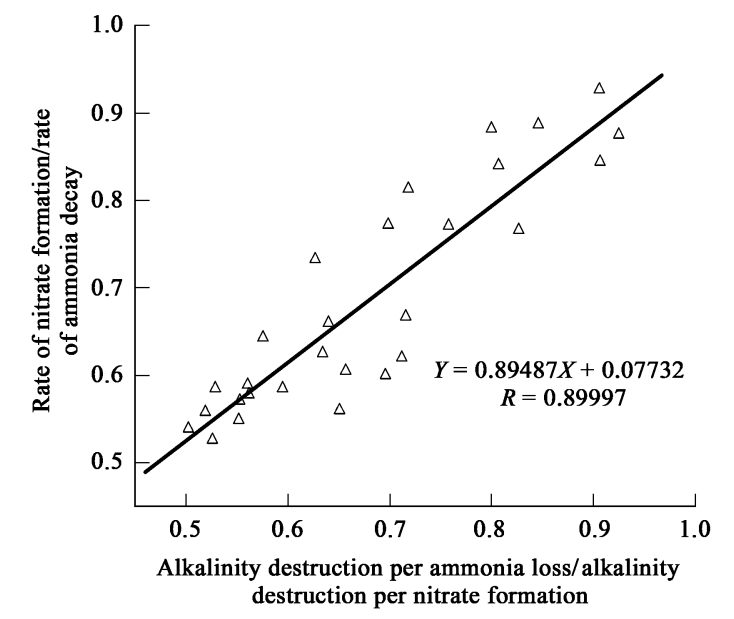

Fig. 2 Comparison of the ratio of alkalinity loss with respect to $\mathrm{NH}_{3}-\mathrm{N}$ decay and $\mathrm{NO}_{x}-\mathrm{N}$ formation with the ratio of $\mathrm{NO}_{x}-\mathrm{N}$ formation to $\mathrm{NH}_{3}$ $\mathrm{N}$ decay. a comparison of the data shown in column 6th and column 9th of Table 4. The production of alkalinity due to simultaneous nitrification and denitrification would have the effect of decreasing the observed rate of alkalinity loss and $\mathrm{NO}_{x}-\mathrm{N}$ formation per $\mathrm{mg}$ of ammonia oxidized. The ratio of $\mathrm{NO}_{x}-\mathrm{N}$ formed to $\mathrm{NH}_{3}-\mathrm{N}$ consumed is expected to be near the theoretical value after accounting for $\mathrm{NH}_{3}-\mathrm{N}$ consumed in synthesis. This ratio would also be reflected in the kinetic rates ammonia consumption and $\mathrm{NO}_{x}-\mathrm{N}$ formation depicted in Table 4. From the figure the data were also consistently less than 1 , which suggested that nitrification and denitrification occurred simultaneously.

\subsection{Dissolved oxygen concentration}

Experiments were performed under low and high aeration flow rate condition to evaluate the influence of DO concentration on the SND. The results are shown in Table 4. With the experimental data in column of 9th and 10th of Table 4, the dependency of the ratio of $\mathrm{NO}_{x}-\mathrm{N}$ formation rate to $\mathrm{NH}_{3}-\mathrm{N}$ decay rate on DO could be depicted in Fig.3. From Fig. 3 the following equations were drawn:

low DO concentration :

$\frac{\Delta \mathrm{NO}_{x}-\mathrm{N}}{\Delta \mathrm{NH}_{3}-\mathrm{N}}=0.07502 \mathrm{DO}+0.53455$

high DO concentration :

$\frac{\Delta \mathrm{NO}_{x}-\mathrm{N}}{\Delta \mathrm{NH}_{3}-\mathrm{N}}=0.07555 \mathrm{DO}+0.54036$

From the figure the dependency of the ratio on DO under low and high DO concentrations respectively was linearity. 

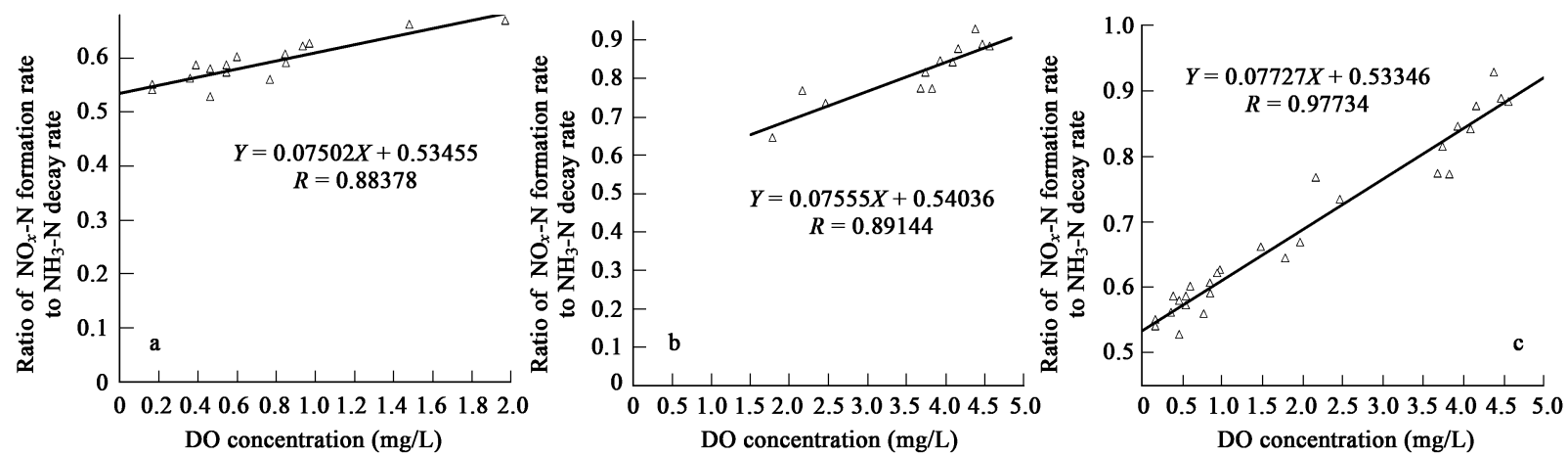

Fig. 3 Relationship of DO concentration and the ratio of the $\mathrm{NO}_{x}-\mathrm{N}$ formation rate to the $\mathrm{NH}_{3}-\mathrm{N}$ decay rate. (a) low aeration flow rate; (b) high aeration flow rate; (c) over all.

The DO concentration showed greatly effects on SND. The overall dependencies of the ratio on DO under both low and high DO concentrations was drawn and expressed as:

$\frac{\Delta \mathrm{NO}_{x}-\mathrm{N}}{\Delta \mathrm{NH}_{3}-\mathrm{N}}=0.07727 \mathrm{DO}+0.53346$

Equation (3) shows that there is an obvious linear relationship between DO concentration and simultaneous nitrification and denitrification. The rate of $\mathrm{NO}_{x}-\mathrm{N}$ formation was almost equal to that of ammonia decay when the DO concentration was $6.05 \mathrm{mg} / \mathrm{L}$. At this DO concentration simultaneous nitrification and denitrification did not happen in the reactor. When the DO concentration was $0.5 \mathrm{mg} / \mathrm{L}$ the rate of $\mathrm{NO}_{x}-\mathrm{N}$ formation was 0.57 times than that of ammonia decay, which was corresponded well with the results of the Munch et al. (1996). In this research the specific relationship of DO concentration and SND was proposed.

\subsection{Floc size}

To test the hypotheses of physical explanation on SND, the activated sludge floc sizes of different experimental conditions were measured and shown in Fig.4. The average floc size of this study was $7.754 \mu \mathrm{m}$, which was significantly smaller than the mean floc diameter reported by Bakti and Dick (1992) of $32 \mu \mathrm{m}$ for nitrifying suspended growth biological reactors, the value of $80 \mu \mathrm{m}$ reported by Beccari et al. (1992). Small floc diameter should be attributed to

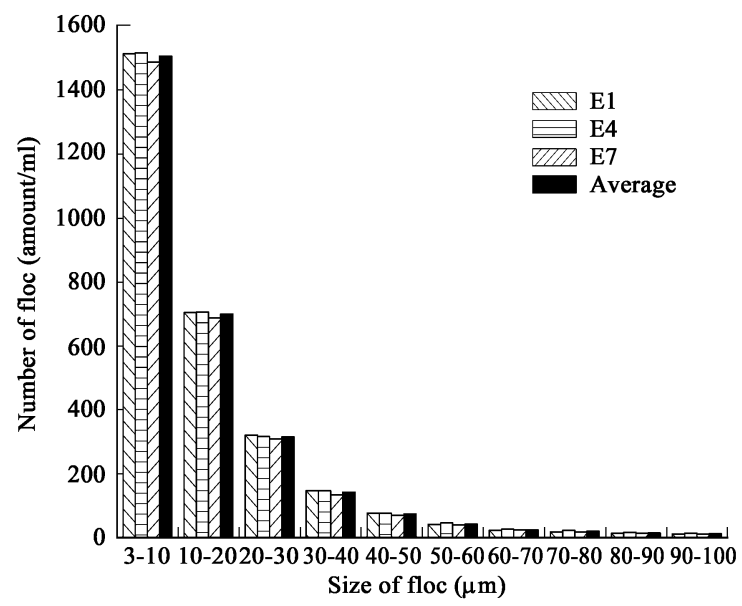

Fig. 4 Floc size under the experimental condition of E1, E4 and E7. the influent characteristic. Compared with the real municipal sewage the synthetic wastewater is more simplex in constitute and content. The large floc parameter is likely to promote the SND due to diffusional limitation of oxygen in the floc. But in such small floc size it is impracticable to produce DO concentration gradients within microbial flocs leading to denitrification in this area (Hisashi et al., 2003; Li and Bishop, 2004), which remarkably clarify the incorrectness of physical explanation standpoint.

\section{Conclusions}

The laboratory pilot scale studies were conducted to evaluate the simultaneous nitrification and denitrification in step feeding biological nitrogen removal process. The results demonstrated that the biological occurrence of simultaneous nitrification and denitrification was obvious in step feeding process, even under high DO concentration. There was a distinct linear relationship between the ratio of ammonia decay rate to $\mathrm{NO}_{x}-\mathrm{N}$ formation rate and $\mathrm{DO}$ concentration. The mathematical expression of SND with DO concentration was proposed to be: $\frac{\Delta \mathrm{NO}_{x}-\mathrm{N}}{\Delta \mathrm{NH}_{3}-\mathrm{N}}=0.07727 \mathrm{DO}+$ 0.53346 . In addition, it is verified that the phenomenon of simultaneous nitrification and denitrification should not solely attribute to physical matter.

\section{References}

APHA, 1995. Standard methods for the examination of water and wastewater[S]. 19th ed. American Public Health Association/American Water Works Association/Water Environment Federation. Washington DC, USA.

Baccari M, Pinto D, Ramadori A C et al., 1992. Effects of dissolved oxygen and diffusion resistance on nitrificatioin kinetics[J]. Wat Res, 26: 1099-1104.

Bakti N A K, Dick R I, 1992. A model for a nitrifying suspended-growth reactor incorporating intraparticle diffusional limitation[J]. Wat Res, 26: 1681-1690.

Bruce E R, Perry L M, 2001. Environmental biotechnology: principles and applications[M]. New York: Metcalf and Eddy, Inc. McGraw-Hill.

Gorgun E, Artan E, Orhon D et al., 1996. Evaluation of nitrogen removal by step feedinging in large treatment plants $[\mathrm{J}]$. Wat Sci Tech, 34(1/2): 253-260.

Hisashi Satoh, Yoshiyuki Nakamura, Hideki Ono et al., 2003. Effect of oxygen concentration nitrification and denitrification 
in single activated sludge flocs[J]. Biotechnol Bioeng, 83: 604-607.

Kim Joong Kyun, Park Kyoung Joo, Cho Kyoung Sook et al., 2005. Aerobic nitrification-denitrification by heterotrophic Bacillus strains[J]. Bioresource Technology, 96: 18971906.

Larrea L, Larrea A, Ayesa E et al., 2001. Development and verification of design and operation criteria for the step feeding process with nitrogen removal[J]. Wat Sci Tech, 43: 261-268.

Li B K, Bishop P, 2004. Micro-profiles of activated sludge floc determined using microelectrodes[J]. Water Res, 38: 12481258.

Munch E V, Lant P A, Keiler J, 1996 Simultaneous nitrification and denitrification in bench-scale sequencing batch reactors[J]. Wat Res, 30: 277-284.

Watnabe Y, Okabe S, Hirate K et al., 1995, Simultaneous removal of organic materials and nitrogen by microaerobic biofilms[J]. Wat Sci Tech, 31: 195-203.

Zhu G B, Peng Y Z, Wang S Y, 2005. Automatic control strategy for step feeding biological nitrogen removal process[J]. Journal of Environmental Sciences, 17: 455-457.

Zhu G B, Peng Y Z, Wu S Y et al., 2007a. Effect of influent flow rate distribution on the performance of step-feeding biological nitrogen removal process[J]. Chemical Engineering Journal, 131: 319-328.

Zhu G B, Peng Y Z, Li B K et al., 2007b. Biological removal of nitrogen from wastewater[J]. Reviews of Environmental Contamination and Toxicology, 192: 159-195.

Zhu G B, Peng Y Z, Wang S Y. 2007c. Hydraulic method of controlling solids retention time in step feeding biological nitrogen removal process[J]. Environmental Engineering Science. 2007, 24 (8): 1111-1120. 